Actes de l'atelier Langue de spécialité du 33 e congrès de la SAES

\title{
Through the looking glass: a trip inside the L2 reader's head
}

Gail Taillefer

\section{(2) OpenEdition}

Journals

Édition électronique

URL : http://journals.openedition.org/asp/4223

DOI : 10.4000/asp.4223

ISSN : 2108-6354

Éditeur

Groupe d'étude et de recherche en anglais de spécialité

Édition imprimée

Date de publication : 1 février 1994

Pagination : 21-30

ISSN : 1246-8185

\section{Référence électronique}

Gail Taillefer, «Through the looking glass: a trip inside the L2 reader's head », ASp [En ligne], 3 | 1994, mis en ligne le 19 février 2014, consulté le 19 avril 2019. URL : http://journals.openedition.org/ asp/4223 ; DOI : 10.4000/asp.4223

Ce document a été généré automatiquement le 19 avril 2019

Tous droits réservés 


\title{
Through the looking glass: a trip inside the L2 reader's head
}

\author{
Gail Taillefer
}

1 "Les étudiants en mal de lecture" headlines the education pages of Le Monde, January 28, 1993, prefacing the results of a large-scale survey of reading practices of French students in higher education. If reading enjoys a generally positive image among students in different types of post-secondary education, cloudy areas show up in certain sectors where up to $42 \%$ admit having slight or serious reading problems-, and along geographic, gender and social lines. Reading for pleasure takes second place to more utilitarian reading for studies; works other than class notes and recommended textbooks are "neglected" as being indirectly related to success on exams; student-teacher exchanges on reading rarely occur due to lack of time, lack of space, lack of tradition. Students are described as being unhappy, frustrated readers: "Coincés entre leur désir de lecture, l'anxiété de la réussite aux examens et les règles très codifiées des études supérieures".

2 And students of foreign languages? Once again, Le Monde, February 18, 1993, highlights the situation: "Les universités face au défi des langues. Les initiatives... pour tenter de sortir de l'ornière l'enseignement des langues aux étudiants non spécialistes". While teaching for language majors -les spécialistes- has traditionally been the primary concern, nonlanguage majors are beginning to receive the attention they deserve, and objectives of such teaching are currently being discussed. Improving foreign language proficiency can of course be taken as a whole, but component abilities -"skills"- are identifiable and can be scientifically measured (Bachman 1990) and individually emphasized (Barnett 1988; Kern 1989). For non-specialist students the aspect of language proficiency we feel most critical, based on testimony of teachers, professionals, researchers and students themselves (Taillefer 1992), is reading competency. This activity generally precedes other forms of professional communication, and may indeed be the only foreign language skill required of advanced students or professionals. Even if university education seeks to further these students' skills in oral communication and written expression, it must see that graduates are autonomous foreign language readers. 
The students we deal with, however, seem far from this goal. As long ago as 1979, both Moirand and Fade described the "average French student of English" as being unable to handle authentic documents of more than a few paragraphs. Their "reading" was childlike word by word decoding, relying heavily on a bilingual dictionary and translation. The reader was characterized as passive, discouraged and frustrated. Our own research, more than ten years later, reveals little or no change. The great majority of students we see are trapped in a vicious circle. Lacking motivation, they set no reading goals for themselves and tend to read everything in the same manner. Consequently, their reading strategies are poorly adapted to the task at hand, leading to poor comprehension. Not understanding the text, they quickly lose interest; bored, they lack motivation.

If "pedagogy" in foreign language teaching has come far enough out of the closet to deserve political debate, its credibility, in any case, depends on its scientific rigor; to be effective, teaching measures must be based on research. Research on foreign/second language reading is still a rather narrow field. A key concept which has been brought to light is the relation between native (L1) and non-native (L2) reading (Alderson 1984; Carrell 1991), so it seemed logical to compare English reading comprehension to the same proficiency in French. Our research results (Taillefer 1992, 1993) support the interactive definition of reading as a cocktail of reader- and text-linked variables involved in the personal construction of meaning; depending on the cocktail shaker, the end result may vary significantly. From a cognitive perspective, reading in both L1 and L2 thus share the same variables, but their proportions differ in each situation, influencing both the reading process-reading strategies- and its product -comprehension. An in-depth study of 39 second year DEUG social science students reading in L1 and L2 thus showed that 24 subjects read significantly less well in English, either on the strategy level, the comprehension level, or most often, on both.

5 A key finding was the positive correlation of efficient strategy use and comprehension scores in both languages (L1: Spearman $r=0.59 ; \mathrm{L} 2: \mathrm{r}=0.88, p<0.05$ ). The correlation was, not surprisingly, stronger in L2 since both reading behavior and comprehension varied to a greater extent in English than in French. Comprehension scores were obtained by means of an immediate oral recall protocol; reading strategies were explored with a questionnaire (given in Taillefer 1992, 1993) following text recall, covering the global approach to reading as well as the more local problem-solving techniques. It was the local strategies which both related most significantly to comprehension in $\mathrm{L}^{1}$ and differentiated weak readers from strong ones in passing from L1 reading to L2. Weaker readers, for example, had difficulties in comparing an unknown word to something familiar in either French or English, in analysing word components (prefix, root, suffix), in guessing word meaning, in grammatically analyzing sentences. Among the global strategies relating significantly to L2 comprehension were the ability to detect and correct a wrong track, to make inferences and draw conclusions, to use punctuation where necessary, to differentiate important points from minor ones.

Given this relation between the way a reader reads and what s/he understands (with no implication of causality), we wanted to put into practice the theoretical insights gained and the empirical lessons learned. This practical application was not formally designed with control and experimental groups or a before and after protocol to test the advantages of teaching reading strategies. Rather, it was seen as a first approach on a metacognitive level for students who, we assumed, had never consciously considered the act of reading in English (or perhaps in French). It was a case of "spreading the good 
word" of reader awareness, and of obtaining primarily qualitative feedback from the students. The findings are thus more of an informational nature than of a statistical one.

\section{Method}

7 Subjects were randomly chosen TD groups of AES students, two from second year, one from first, totalling 68 in all. Wanting to raise students' consciousness of themselves as L2 readers -via a realization of what they do in the L1 context- and to, hopefully, give them the tools to become autonomous readers of English, we decided to use the recently published Compréhension écrite en anglais pour les sciences humaines (Billant \& Fade 1992) as the basis for reading instruction. This guide is the only one of its kind, to our knowledge, adopting the L1-L2 perspective for students in the humanities. Examples of reading difficulties are first presented in French before transferring to English, and the mother tongue is used for explanations and exercises to ensure comprehension on a conceptual level, to avoid burdening the non-specialist student with the intricacies of perfect translation. It covers key vocabulary and grammar problems common to French students in pre-professional reading, and includes a structured methodology section, texts on which to "practice" and a correction key. ${ }^{2}$

The book was designed to be used in itself as a reading course, but we had to "share" time with other activities. Thus, only five two-hour sessions were spent with it, with one additional session for testing and correction. Vocabulary was highlighted in class, and all grammar explanations and methodological explanations were reviewed together, leaving all exercises for homework. A limited number of "practice" texts were then used. Corrections were done by the students themselves in pairs, while we checked around and explained discordances, as explanations of possible wrong answers do not figure in the answer key.

9 Before beginning with the textbook, however, we "gently" introduced the idea of a metacognitive approach to reading by means of a brief exercise, to signal to the students that the work about to be undertaken was a trip inside their head and not just "ordinary" reading exercises. It was important to us for the students to realize that if the short term goal was understanding how to read more efficiently, ${ }^{3}$ the long term objective was transferring the reading strategies to future reading tasks. Thus, we gave them a long, complex text in French from Le Monde, and asked them to read it as if they had to use the document for study purposes. We told them to note down, as they worked through the text, what they were doing: for example, checking the title and the author, reading the introduction and the subtitles, looking for key words... As we expected, this task seemed quite strange to the students, but with examples and individual checking, they completed it in about 15 minutes. We then led a discussion of reading strategies for study purposes in French, asking students individually what they had done first, next, etc. Following that, we asked them what they would do in the same circumstances in English. Needless to say, the answers were quite different, and often expressed with ironic laughter; the thought of reading such a document as a means to an end rather than as an end in itself (to answer "classic" comprehension questions) was something new.

10 Having thus primed the students, we embarked on our five-week trip, ending with a test of the reading skills studied. Only those reading skills employed were assessed, and not the reutilization of information obtained -the logical conclusion to a reading course. But given time constraints -the test took over an hour-- we decided in this case to 
concentrate solely on the skills aspect. For the sake of test validity (Bachman 1990), we used one of the "practice" texts not done together, adding questions on the vocabulary and grammar covered by the book. There was, of course, the risk that motivated students might have already worked on that text alone, with the correction key, ${ }^{4}$ but we preferred to take that risk to guarantee test objectivity, and explained same to the students. Answers could be given in either English or French, true to the spirit of the book and the treatment of the exercises; evaluation of reading comprehension did not -and should not- depend on proficient written expression. After grading the test, it was corrected with the students just as the earlier exercises had been, and comprehension difficulties were discussed.

11 Our short term goal was, as stated before, making students aware of the reading process in L2, so feedback other than assessing their actual mastery of reading skills was necessary, and we asked them to evaluate the reading module. This was done before returning the graded test so that satisfaction (or insatisfaction) would not influence judgment. Two questions were asked to be answered anonymously in writing (in French): How do you evaluate the book as a working instrument? What about the way we handled the book? Answers to these questions, both positive and negative, are given below in summary form.

\section{Results}

For the first question, reaction to the book as a whole was overwhelmingly positive. Students agreed the book is well planned and easy to use, with practical application immediately following theoretical explanation. It does not discourage the reader, and is seen to reach its objective of "teaching how to read difficult documents".

Regarding the different sections of the book, the vocabulary is considered by the students to be necessary "since it is not always familiar" and is rarely recognized automatically, an influential factor in efficient cognitive processing of text (Gaonac'h 1990). The few critical observations expressed the desire for a more complete, more advanced offering in a textbook of university level. The grammar section is described as well thought out, clear, concrete, instructive and the exercises, appropriate. The major criticism, aside from the desire for more grammar, was that the exercises were repetitive and became tedious.

The methodology section was highly praised by all, with only one student out of 68 claiming to have touched on these considerations in a foreign language classroom. ${ }^{5}$ Descriptions included such qualifiers as "interesting, new, concrete, progressive", and comments showed that students felt the book enabled them to acquire a method to better structure and understand text, to compensate for lack of vocabulary, to read independently, to handle long texts rapidly and efficiently, and -thanks to pertinent questions- to reflect on material which would probably have been out of reach before.

Reaction to choice of texts in the book was on the whole favorable, although some students found them too long or complex and therefore not motivating. The correction key was seen as useful, but six first year students (out of 23) and one second-year student (out of 43) described the key as "too tempting".

16 The answer to the first question -How do you evaluate the book as a working instrument?- is thus most positive. While one student felt the methods used in the book would be difficult to apply (but gave no further explanation), and a second said it would 
be difficult to use alone, several others expressed regret at not having been exposed to this type of book earlier; they reported having learned how to proceed otherwise than with a fine-tooth comb and a dictionary, saving time and energy and increasing comprehension. They agreed it met a methodological need in English, and that it is a useful tool to keep, much more than "ordinary" class notes. Finally, a most significant insight, from our point of view, came from the student who said the book may have further applications: "Ca peut servir en dehors du cursus scolaire". That, of course, is the question.

17 Some students, inevitably, missed the boat and did not appear to grasp the goal of the book. The difficulty with an anonymous open-question evaluation, rather than a "closed" questionnaire administered during an interview, of course, is that the researcher cannot verify subjects' comprehension of questions, and therefore cannot check on the reason motivating "incoherent" responses. For instance, one student said that while he learned linking words, he did get enough "basic" vocabulary, but the Introduction to the book describes the vocabulary level as "average" and advises students who feel they are weak on this level to make a particular effort. Similar remarks were made by a few students desiring more grammar. Again, the authors clearly state that only those points specifically relevant to reading comprehension are covered. Similarly, two students judged the methodology section less useful than the vocabulary or grammar sections. Such an answer could, of course, indicate that these students are sufficiently evolved L2 readers who do not need to consciously "dissect" the reading process. But it could also reflect a misunderstanding of the book's objective. Because the evaluation was anonymous, it was unfortunately not possible to check either hypothesis against individual test performance. Two final comments, however, leave little doubt in our mind that some students were on different wave lengths: one "complained" the texts gave no opportunity to improve oral expression; another felt that viewing the texts on TV would have been nice...

18 As to the second question -What about the way we handled the book?- the mass of negative answers brings to light the whole question of foreign language training for non specialists and the current debate on pedagogical objectives: what should be the first priority? the second? etc. Compréhension écrite en anglais pour les sciences humaines was designed to be used in itself as a reading course, a luxury we did not have, as the six-week reading module constituted only one component among others in an academic year of 20 weeks (with contrôle continu and legal holidays resulting in even less). Not surprisingly, the majority of students particularly felt the lack of time spent on the material made it difficult to "get to the bottom" of questions and to sufficiently apply and assimilate new information and techniques. A very few second year students, however, would have preferred spending less time in class and more on self study, demonstrating what we feel a more mature reaction than many first year students, overly "tempted" by the correction key. Finally, several students said the corrections were handled too superficially. This reaction might be interpreted as a lack of autonomy -the students are simply not used to self and pair-work correction-, thereby reflecting the need for this type of learner training.

19 On the whole, then, the students rated the book very favorably and consequently regretted having spent too little time with it. This first evaluation of a metacognitive approach to ESP reading was limited by the form of the evaluation itself, as is any type of assessment. A more precise closed-question evaluation covering both the metacognitive 
approach and the pedagogical material used would offer more precise feedback. The question of anonymity is more difficult to resolve, as anonymous answers tend to be more honest, but preclude further investigation of motivation.

The goal of this simple "experiment" was, as we have said, a qualitative step in the direction of reader awareness. The real test of the effectiveness of such an approach is students' long-term ability to transfer the reading knowledge acquired, and implies a more complete before and after protocol in a longitudinal perspective. Nevertheless, the minimal amount of quantitative feedback available -the test scores- are of some interest. Average score for the total sample of 68 students was $11.80 / 20$ (S.D. $=3.20$, median $=11.70$, range $=4.90-17.80$ ), with no significant differences occurring between averages of any of the groups (ANOVA, F = 1.12, $p<0.33$ ). This rather "average" level of mastery -although there are no norms for comparison, to our knowledge- obviously raises questions: how much did they actually learn (i.e., what scores would they have had without studying the material)? how much more would they have learned if they had had more time? to what extent were they really aware of what they were doing? will any of them continue working on the book to complete it alone? Clearly, more research is necessary...

\section{Conclusion}

Given the limited success of these students as autonomous L2 readers (as well as those discussed in Taillefer 1992), and their strong feeling of needing more time to improve, the lesson from this first experience is that of Tony and Maria in West Side Story, "There's a place for us...", i.e., university teachers concerned with ESP reading efficiency. Faced with ever increasing numbers of students from ever more varied backgrounds, and with mounting economic, scientific and political pressures, French universities are now questioning their objectives. Doors are being opened, and language for non-specialists is one of them. Understanding and improving the reading process for these students is, in our opinion, the door handle.

\section{BIBLIOGRAPHIE}

Alderson, J. C. 1984. “Reading in a foreign language: A reading problem or a language problem?"? In Alderson, J. C. \& A. H. Urquhart (eds.), Reading in a Foreign Language. London: Longman, 1-27.

Bachman, L. 1990. Fundamental Considerations in Language Testing. Oxford: Oxford University Press.

Barnett, M. 1988. “Teaching reading strategies: How methodology affects language course articulation". Foreign Language Annals 21/2, 109-119.

Billant, J. \& P. Fade. 1992. Compréhension écrite en anglais pour les sciences humaines. Nancy: Presses Universitaires de Nancy.

Carrell, P. 1991. “Second language reading: Reading ability or language proficiency?”. Applied Linguistics 12, 159-179. 
Fade, P. 1979. "Proposition pour lire”. Mélanges pédagogiques. Nancy: Centre de recherches et d'applications pédagogiques en langues, 31-47.

Gaonac'h, D. 1990. "Lire dans une langue étrangère : approche cognitive”. Revue française de pédagogie 93, 75-100.

Kern, R. G. 1989. “Second language reading strategy instruction: Its effects on comprehension and word inference ability". The Modern Language Journal 73, 135-149.

Moirand, S. 1979. Situations d'écrit : compréhension/production en français langue étrangère. Paris: CLE international.

Taillefer, G. 1992. "Les difficultés de lecture de l'anglais, langue étrangère, chez des étudiants en sciences sociales”. Thèse nouveau régime, Université de Toulouse-Le Mirail.

Taillefer, G. 1993. "What do they understand and how? Second time round... Reading comprehension of students in DEUG Social Sciences". ASp 1, 35-62.

\section{NOTES}

1. ANOVA, see Taillefer (1992).

2. The book was the object of Pascale Fade's communication at the GERAS Colloquium in 1992 which may be found in the first issue of ASp (1993).

3. 3 By "efficient" reading, we mean the ratio between effort expended and useful work done, which can be measured by dividing reading time by score (see Taillefer 1992).

4. In fact, however, no one took such an initiative.

5. Although not a part of the written evaluation, $15 \%$ of the students said, by show of hands, they had been exposed to a metacognitive approach to reading in French.

\section{RÉSUMÉS}

Alors qu'il existe une «Mission lecture " pour évaluer la performance de lecture des élèves et étudiants dans leur langue maternelle, le besoin se fait sentir d'un outil semblable pour la langue 2. En anglais de spécialité, il convenait de mettre en place des formations destinées à développer la compétence de lecture. L'auteur présente ici une évaluation quantitative et qualitative du travail mené en ce sens à partir de l'ouvrage de J. Billant et $\mathrm{P}$. Fade Compréhension écrite en anglais pour les sciences humaines (1992).

While there is a "Mission Lecture" to study students' reading in L1, the need for such study in L2 is none the less important, and may even be more so (to people like ourselves). There is a need for developmental reading courses in English for Specific Purposes. Research on reading strategies has enabled the identification of different reading profiles as a function of $\mathrm{L} 1$ reading competency and L2 language acquisition. Based on this year's work with J. Billant et P. Fade Compréhension écrite en anglais pour les sciences humaines (1992), a qualitative and quantitative evaluation of the effect and importance of such teaching was carried out. In conclusion "there's a place for us", i.e., there is consciousness raising in ESP reading. 
INDEX

Mots-clés : acquisition des langues, lecture, stratégie d'apprentissage

Keywords : language acquisition, reading, strategy (learning)

\section{AUTEUR}

GAIL TAILLEFER

Gail Taillefer teaches at Université Toulouse 1. gail.taillefer@ut-capitole.fr 